Doi: HTTPS://DOI.ORG/10.23910/IJEP/2019.6.3.0327

\title{
First Report of Colletotrichum gloeosporioides Causing Leaf Spot Disease on Areca Palm (Chrysalidocarpus lutescens $\mathrm{H}$. Wendl.) in India
}

\author{
Disha D. Desai, P. R. Patel and V. P. Prajapati*
}

Dept. of Plant Pathology, ASPEE College of Horticulture and Forestry, NAU, Navsari, Gujarat (396 450), India

\section{Corresponding Author}

V. P. Prajapati

e-mail: virpathologist@nau.in

\author{
Article History \\ Article ID: IJEP0327 \\ Received in $13^{\text {th }}$ August, 2019 \\ Received in revised form $23^{\text {rd }}$ August, 2019 \\ Accepted in final form $28^{\text {th }}$ August, 2019
}

\begin{abstract}
Colletotrichum gloeosporioides is known to have a wide host range and has become progressively more important pathogen on many economic crops worldwide. C. gloeosporioides was isolated for the first time from areca palm (Chrysalidocarpus lutescens $\mathrm{H}$. Wendl.) in south Gujarat region. C. gloeosporioides was classified based on the morphological characteristics. To the best of our knowledge, this is the first report of $C$. gloeosporioides causing leaf spot of areca palm in India.
\end{abstract}

Keywords: Areca palm, leaf spot, morphology, pathogenicity

\section{Introduction}

Chrysalidocarpus lutescens is a flowering plant in the family arecaceae belonging to class monocotyledon and is native to Madagascar. It is also known as golden cane palm, areca palm, yellow palm and butterfly palm. It is grown in tropical and subtropical regions as ornamental plant in gardens as well as indoor plant. It grows 6-12 $m$ in height with multiple stems emerging from base. The leaves are arched, 2-3 m long and pinnate with 40-60 pairs of leaflets. "Butterfly Palm" refers to the leaves which curve upwards in multiple stems to create a butterfly look.

As it is an ornamental plant and its foliage is having ornamental value, diseases infecting foliage parts reduces its aesthetic and market value. The Colletotrichum leaf spot is new, the most occurring and destructive disease of areca palm. Leaves with light to dark brown spots having ashy grey center, surrounded by dark brown margins and yellow halo, showing typical shot-hole symptoms were observed during winter 2017-18 at Navsari Agricultural University, Navsari, Gujarat, India.

\section{Materials and Methods}

\subsection{Collection of disease samples}

The diseased leaf samples of areca palm showing typical leaf spot symptoms were collected from floriculture farm of ASPEE College of Horticulture and Forestry, Navsari Agricultural University, Navsari.

\subsection{Isolation of pathogen}

The samples were brought to the P. G. Research Laboratory,
Department of Plant Pathology, ACHF, NAU, Navsari. The standard tissue isolation technique was used to isolate the fungus. The infected portion of the leaf bits were thoroughly washed and cut into small pieces $(1 \mathrm{~mm})$ in such a way that each piece consisted of infected as well as healthy green tissues. The pieces were surface sterilized with sodium hypochlorite (1\%) solution for 30 seconds followed by three subsequent washing with sterilized distilled water to remove the traces of chemical if any and then left for drying. After drying, the sterilized pieces were transferred to sterilized Petri plates containing $20 \mathrm{ml}$ Potato Dextrose Agar (PDA) media under aseptic conditions. These Petri plates were then placed in BOD incubator at $27 \pm 1^{\circ} \mathrm{C}$ for 12 days.

\subsection{Morphological identification}

For morphological studies of the pathogen, a loopful pure culture of the isolated pathogen from 12 days old culture was placed on the slide and mixed thoroughly with lactophenol to obtain uniform spread. A cover slip was placed over it. Length and breadth of the spores were measured under high power objective by using 'SCOPETEK' software under microscope. The average size, shape and colour of the spores were measured. Further, the pure cultures of isolated pathogen were sent to Indian Type Culture Collection (ITCC), Division of Mycology and Plant Pathology, ICAR-Indian Agricultural Research Institute, New Delhi for identification and confirmation of isolated pathogen.

\subsection{Pathogenicity}

One-year-old areca palm seedlings raised in $10 \times 10$ inch $^{2}$ polythene bags were brought from nursery for proving the 
pathogenicity. The pathogenicity test was carried out by using three methods viz., spraying spore suspension, pin prick injury and toothbrush injury method. The inoculum suspension $\left(1 \times 10^{7}\right.$ spores $\left.\mathrm{ml}^{-1}\right)$ from 12 days old pure culture was used in all the three methods. Three repetitions per method were maintained. The leaves to be inoculated were thoroughly cleaned with distilled water. Three leaves were inoculated in each plant, so in total nine leaves were inoculated per method. The observation regarding symptom development was recorded regularly. The re-isolation of pathogen from artificially inoculated plants was compared with originally isolated pathogen from diseased plant to prove the Koch's postulates. Suitable control plants were also maintained.

Per cent Disease Index (PDI) was worked out as per the standard grade chart given below (Athira, 2017).

\begin{tabular}{lc}
\hline Grade & Description (\% leaf area infected) \\
\hline 0 & No sign or symptom \\
1 & $0-10$ infection \\
3 & $11-15$ infection \\
5 & $16-25$ infection \\
7 & $26-50$ infection \\
9 & $>50$ infection \\
\hline
\end{tabular}

Per cent Disease Index (PDI) was worked out as described by Mckinney's (1923).

$\mathrm{PDI}=(\Sigma$ of ratings of infected leaves observed/ No.of leaves observed×Maximum disease grade) $\times 100$

\section{Results and Discussion}

\subsection{Symptomatology}

The disease began as circular to irregular spots which enlarged as the disease progressed. Later, the spots were light to dark brown in colour having ashy grey center, surrounded by dark brown margins and yellow halo (Figure 1A). In severe cases, the adjacent spots eventually coalesced to form large irregular patches leading to shot-hole symptoms and finally covered the entire leaf lamina turning the leaf colour to pale yellow (Figure 1B).

\subsection{Isolation and identification of the pathogen}

Standard tissue isolation technique was followed to obtain Colletotrichum gloeosporioides from the infected leaves of areca palm, showing typical leaf spot symptoms (Figure 1A). The isolations (Figure 1C) were repeated several times to obtain pure culture (Figure 1D). The yielded pure culture of Colletotrichum gloeosporioides was maintained on PDA slants and Petri plates at $27 \pm 1^{\circ} \mathrm{C}$ in BOD incubator for further investigation.

The fungus produced conidia (Figure 1F) that were hyaline, thin walled, straight, oblong and bacilliform; containing two oil droplets. The conidia measured 10.99-16.54 $\mu \mathrm{m}$ length $\times 3.575 .59 \mu \mathrm{m}$ width. Mycelial growth on PDA was observed as white cottony growth which finally turned grey and showed orange fungal ooze. The hyphae were thin, branched, hyaline and septate (Figure 1E).
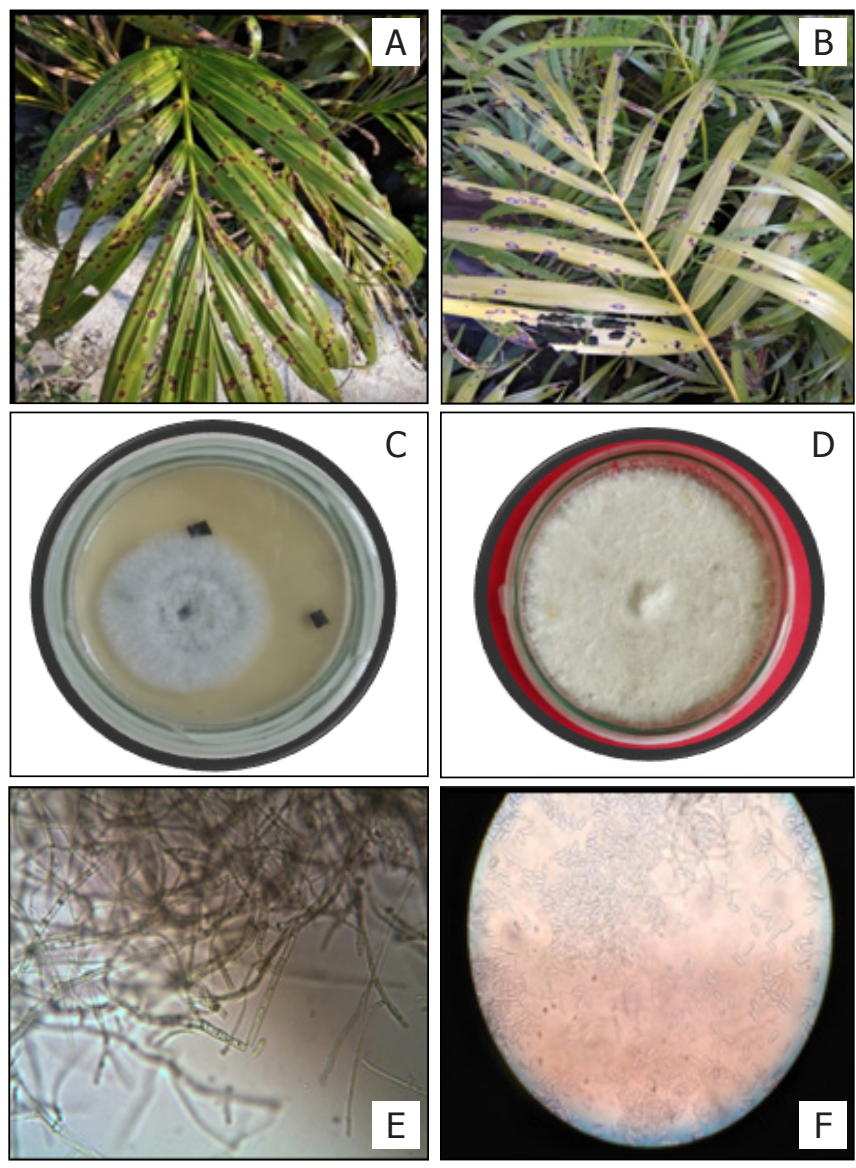

Figure $1 \mathrm{~A}$ : Leaf spot of areca palm. B- Entire leaf lamina turning into pale yellow colour and showing shot-hole appearance. C- Isolation of fungus from leaf spot, D- Pure culture of C. gloeosporioides. E-Septate mycelia, F-Profuse sporulation of $C$. gloeosporioides

The fungus was identified on the basis of typical morphological characters of mycelium and spore structure. The pure culture of pathogen was sent for identification to Indian Type Culture Collection (ITCC), Division of Plant Pathology, ICAR-IARI, New Delhi 110012 and identified as Colletotrichum gloeosporioides (ITCC No. 10,907.18). Thus, Colletotrichum sp. under study was identified and confirmed as Colletotrichum gloeosporioides.

\subsection{Pathogenicity}

Pathogenicity was carried out as described in materials and methods using three different methods viz., spraying spore suspension, pin prick injury method and toothbrush injury method. The isolated fungus Colletotrichum gloeosporioides was inoculated into healthy one-year-old areca palm seedlings. The results clearly revealed that $C$. gloeosporioides was capable of infecting the leaves of areca palm. The results are presented in Table 1 and Figure 2. The symptoms appeared on 
Table 1: Pathogenicity of Colletotrichum gloeosporioides on areca palm

\begin{tabular}{llc}
\hline SI. No. & Inoculation technique & Per cent disease index \\
\hline 1. & Spraying spore suspension & 09.80 \\
2. & Pin prick injury & 82.70 \\
3. & Toothbrush injury & 40.00 \\
4. & Control & 00.00 \\
\hline
\end{tabular}

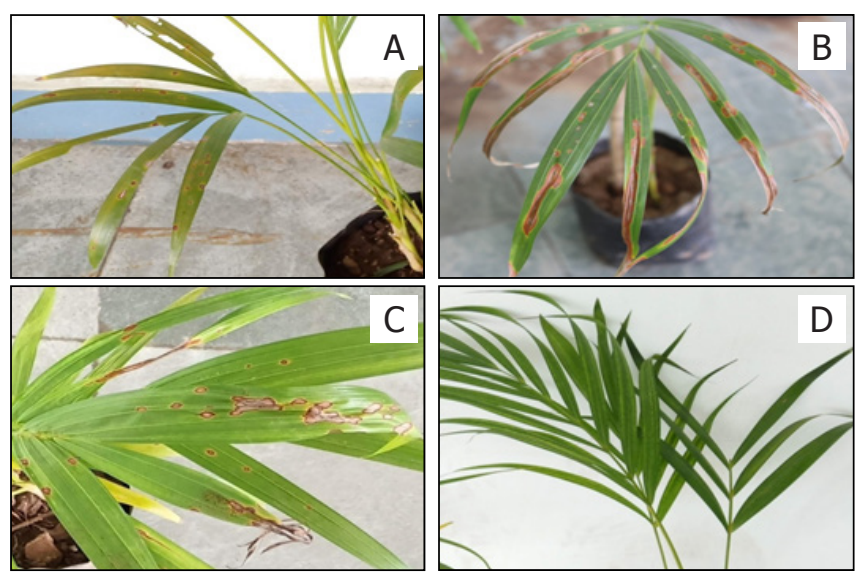

Figure 2: Pathogenicity A: Spraying spore suspension; B: Pin prick injury; C: Toothbrush injury D: Control

inoculated leaves as circular to irregular dark brown spots after 25 days of inoculation. The Per cent Disease Index was worked out and it was found that maximum symptoms were observed in pin prick injury method (82.7\%) followed by toothbrush injury (40\%) and spraying spore suspension (9.8\%). The plants maintained as control showed no development of disease symptoms. Reisolation made from artificially inoculated plants yielded the identical pathogen as original culture.

No work has been done on areca palm till date. Only Chou et al. (2019) did his research on areca palm incited by $C$. siamense and all the results match with his findings.
Similar morphological characteristics of Colletotrichum gloeosporioides were observed by Sonwane (2013) and Gautam (2014). Chou et al. (2019) proved pathogenicity of Colletotrichum siamense on areca palm by pin prick and spore suspension $\left(10^{5}\right.$ conidia $\left.\mathrm{ml}^{-1}\right)$ method. Sonwane (2013) proved pathogenicity of Colletotrichum gloeosporioides affecting anthurium and obtained maximum symptoms through pin prick injury method.

\section{Conclusion}

The pathogen causing leaf spot on areca palm was isolated and identified as Colletotrichum gloeosporioides. However, on the basis of literature, this is the first report from India showing that $C$. gloeosporioides causes leaf spot on areca palm.

\section{References}

Athira, K., 2017. Survey, identification and estimation of damage in major diseases of coconut. International Journal of Current Microbiology and Applied Science 6, 416-423.

Chou, T., Xu, W., Mukhtar, I., Quan, X., Jiang, S., Huang, R., Chen, B., Xie, B., 2019. First report of leaf spot disease caused by Colletotrichum siamense on Chrysalidocarpus lutescens. Available from https: // apsjournals. apsnet. org /doi/10.1094/PDIS-11-18-2049-PDN.

Gautam, A.J., 2014. Colletotrichum gloeosporioides: Biology, Pathogenicity and Management in India. Journal of Plant Physiology and Pathology 2, 2.

Mckinney, H.H., 1923. A new system of grading plant diseases. Journal of Agricultural Research 26, 195-218.

Sonwane, S.K., 2013. Investigation and management of leaf blight (Colletotrichum gloeosporioides) of anthurium (Anthurium andraeanum). M.Sc. (Horticulture), thesis submitted to Navsari Agricultural University, Navsari. 